\title{
PENGUKURAN TINGKAT MOTILITAS SPERMA BERDASARKAN LINEARITAS SPERMA MENGGUNAKAN METODE ADAPTIVE LOCAL THRESHOLD DAN ELLIPSE DETECTION
}

\author{
Priyanto Hidayatullah $^{1^{*}}$, M. Nuriyadi ${ }^{2}$, Iwan Awaludin ${ }^{1}$, Reyhan Damar Kusumo ${ }^{1}$ \\ ${ }^{1}$ Computer Engineering and Informatics Department, Bandung State Polytechnic \\ ${ }^{2}$ Refrigeration Department, Bandung State Polytechnic \\ *Penulis korespondensi; Email: priyanto@polban.ac.id
}

\begin{abstract}
Abstrak: Teknologi yang dapat digunakan untuk membantu mengukur tingkat kesehatan sperma adalah Computer-Aided Sperm Analysis (CASA). Kekurangan CASA adalah harganya yang mahal serta metode yang digunakan dalamnya tidak terbuka untuk umum. Telah banyak penelitian untuk membuat alternatif CASA yang akurat, murah, dan cepat. Penelitian ini difokuskan untuk mengukur tingkat motilitas sperma. Pengamatan motilitas sperma secara visual sangat bergantung kepada setiap androlog sehingga bersifat subjektif dan tidak memungkinkan untuk dilakukan pengulangan terhadap sampel yang sama. Pengamatan secara visual juga tidak dapat memberikan nilai presisi untuk parameter yang berpengaruh terhadap pola gerak sperma yaitu VSL, VCL, dan LIN.Fokus penelitian ini adalah membuat aplikasi yang memanfaatkan metode pendeteksi sperma Adaptive Local Threshold dan Ellipse Detection untuk mengukur linearitas setiap sperma untuk menentukan tingkat motilitasnya sesuai dengan standar WHO.Hasil uji coba menghasilkan output dengan selisih hasil analisis terkecil sebesar 5,7333\% dan terbesar sebesar 10,4667\% dibandingkan hasil analisis secara visual oleh androlog.
\end{abstract}

Kata kunci: Computer-Aided Sperm Analysis, Motilitas Sperma, Linearitas Sperma

\begin{abstract}
Technology that can be used toassist sperm examination is Computer-Aided Sperm Analysis (CASA). The problems with this technology are expensive and the methods are not open for public. A lot of researches have been done to have an altenative CASA's method to examine sperm quality accurately, inexpensively, and fast. This research is focused on measuring the level of sperm motility. Visual observations of sperm motility greatly depend on each andrologists which are subjective and also the possibility of repetition for the examined sample does not exist. Moreover, visual observation cannot provide precise values for parameters that affect the sperm motion patterns which are Velocity Straight Line, Velocity Curvilinear Line, and Linearity. Focus of this research is to create an application using sperm detection method, Local Adaptive Threshold and Ellipse Detection to measure sperm linearity to determine the level of sperm motility based on the WHO standard. Experiment produces result with the smallest difference $5.7333 \%$ and the biggest difference $10.4667 \%$ compared to the result of visual analysis by andrologist.
\end{abstract}

Keywords: Computer-Aided Sperm Analysis, Sperm Motility, Sperm Linearity

\section{PENDAHULUAN}

Saat ini teknologi yang dapat digunakan untuk membantu mengukur tingkat kesehatan sperma dengan bantuan kamera dan komputer adalah Computer-Aided Sperm Analysis (CASA). Kekurangan dari teknologi tersebut adalah harganya yang mahal, sehingga hanya sedikit laboratorium uji yang memilikinya dan akhirnya pengukuran kualitas sperma yang sering dilakukan adalah menggunakan analisis visual oleh androlog [1]. Hasil analisis oleh androlog yang berbeda terhadap sampel uji yang sama dapat menimbulkan permasalahan baru disebabkan oleh kondisi, pengetahuan, dan pengalaman setiap androlog yang berbeda-beda sehingga terkesan subjektif dan juga tidak memungkinkan untuk dilakukan pengulangan terhadap sampel yang sama. Selain itu, pengukuran secara visual masih dapat menghasilkan nilai hasil perhitungan jumlah sperma yang layak, namun tidak dengan nilai parameter pergerakan sperma seperti curvilinear velocity (VCL), straight-line velocity (VSL), linearity of forward progression (LIN) dan amplitude of lateral head displacement (ALH) yang semakin dipercaya secara klinis memiliki efek signifikan terhadap prediksi infertilitas [2]. Cara kerja serta metode yang digunakan dalam software CASA tidak terbuka untuk umum, sehingga telah banyak penelitian yang dilakukan untuk mempelajari cara kerja serta metode dasar dalam mengukur tingkat kesehatan sperma secara akurat, murah, dan cepat [3].

Kualitas sperma diukur berdasarkan, diantaranya: volume air mani, jumlah sperma, kepadatan sperma, pergerakan sperma (motilitas), kecepatan sperma, bentuk sperma (morfologi), dan viabilitas sperma [4]. Pada penelitian ini hanya difokuskan untuk mengukur tingkat motilitas sperma berdasarkan linearitas sperma. 
Linearitas sperma adalah tingkat linearitas lintasan gerak sperma [4]. Metode pengukuran linearitas sperma yang digunakan adalah berdasarkan standar prosedur manual WHO untuk pengujian semen manusia dimana variabel yang dibutuhkan untuk mengukur linearitas sperma adalah VSL, VCL, dan LIN [4]. Linearitas sperma akan digolongkan menjadi 3 kategori, yakni A, B, dan C [5].

Untuk mengukur pergerakan sperma dalam video diperlukan metode pendeteksi sperma. Salah satu metode pendeteksi sperma adalah Adaptive Local Threshold (ALT) dan Ellipse Detection (ED). Metode tersebut bekerja dengan cara memisahkan background dengan objek yang akan dideteksi, menghilangkan objek-objek yang tidak diinginkan, kemudian mendeteksi elips, yang diasumsikan sebagai bagian kepala sperma. Metode pendeteksi sperma dengan menggunakan Adaptive Local Threshold dan Ellipse Detection memiliki tingkat akurasi deteksi hingga $90.97 \%$ [3].

\section{METODE PENGUKURAN LINEARITAS SPERMA}

Untuk mengukur tingkat linearitas sperma langkah utama yang perlu dilakukan adalah mendeteksi posisi sperma serta mengukur nilai parameter terkait linearitas sperma.

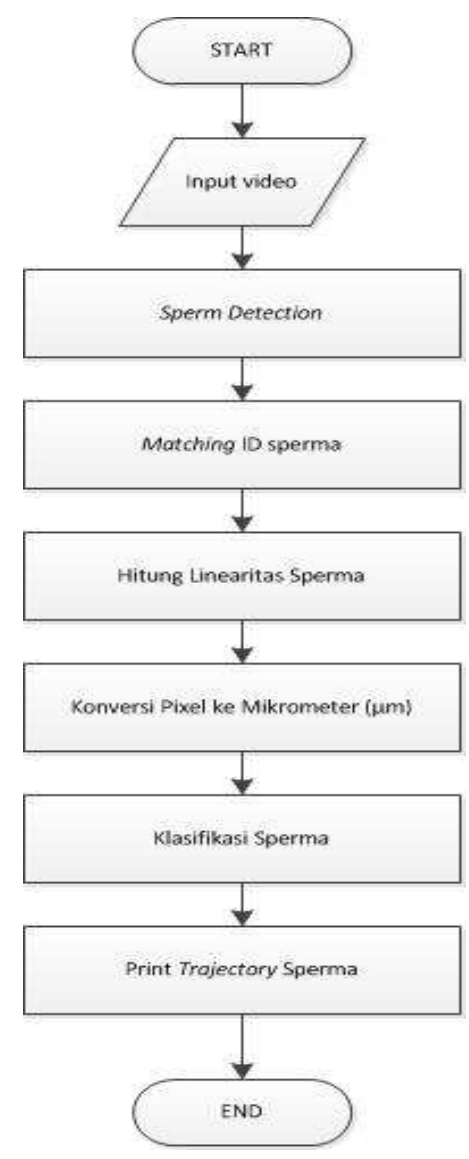

Gambar 1. Alur Proses Aplikasi Pengukur Linearitas Sperma

\section{Metode Pendeteksi Sperma}

Metode pendeteksi sperma berbasis Adaptive Local Treshold dan Ellipse Detection yang dirancang pada [3] bekerja dengan input berupa citra per frame dari video. Metode ini bekerja dengan cara memisahkan background dengan objek yang akan dideteksi, menghilangkan objek-objek yang tidak diinginkan, kemudian mendeteksi elips, yang diasumsikan sebagai bagian kepala sperma. Metode ini dapat ditulis dengan langkah-langkah sebagai berikut:

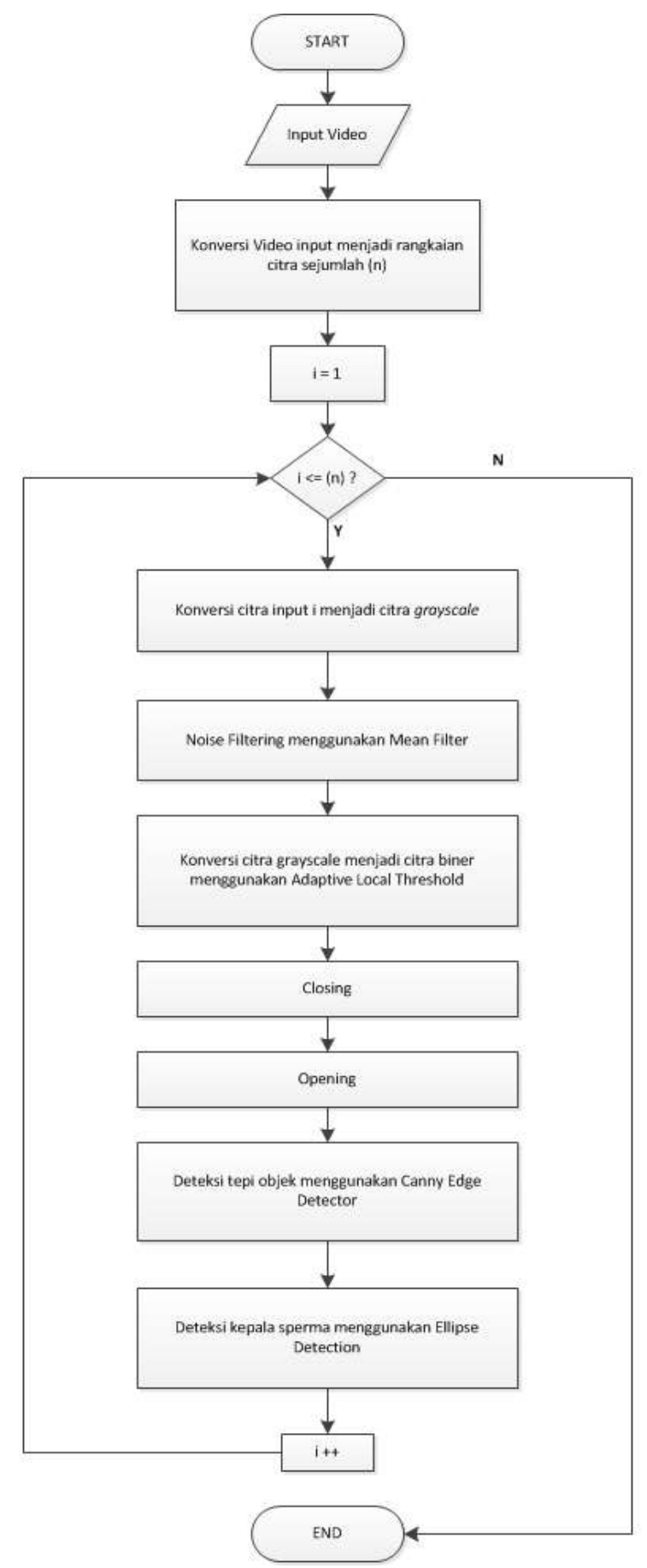

Gambar 2. Alur Proses Metode Pendeteksi Sperma 


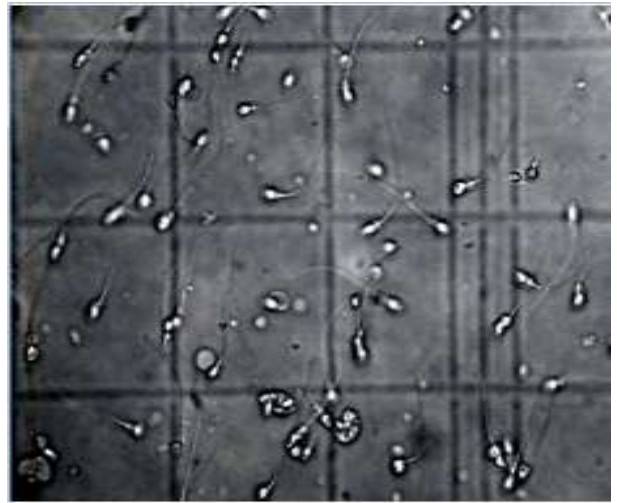

Gambar 3. Hasil Grayscaling

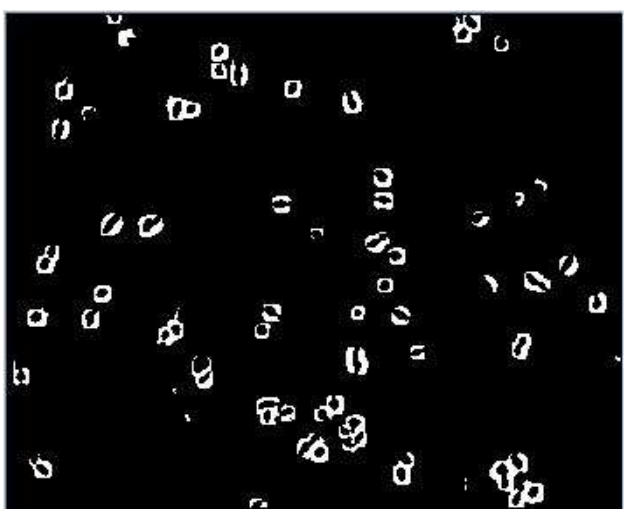

Gambar 4. Hasil Binarisasi

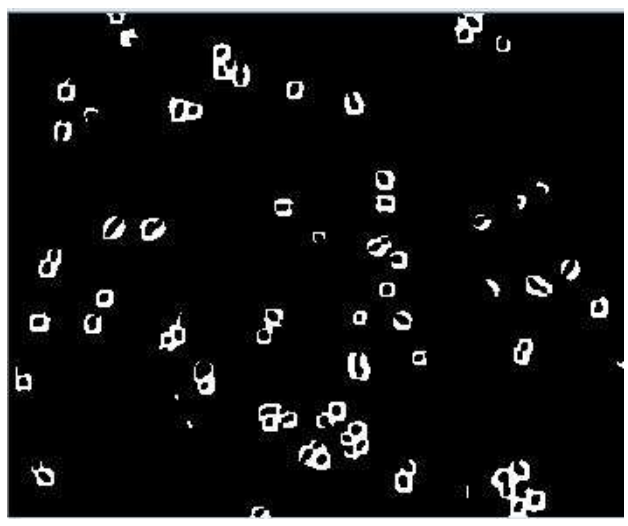

Gambar 5. Hasil Closing

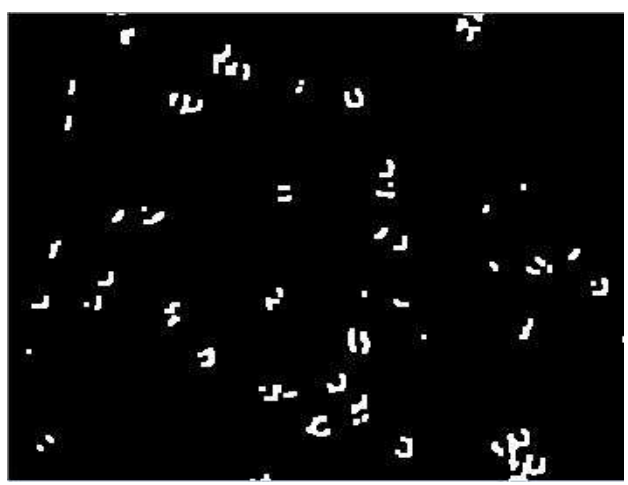

Gambar 6. Hasil Opening

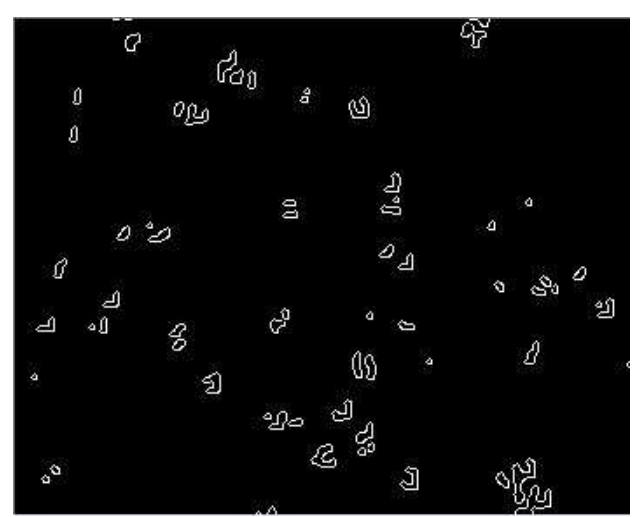

Gambar 7. Hasil Canny Edge Detection

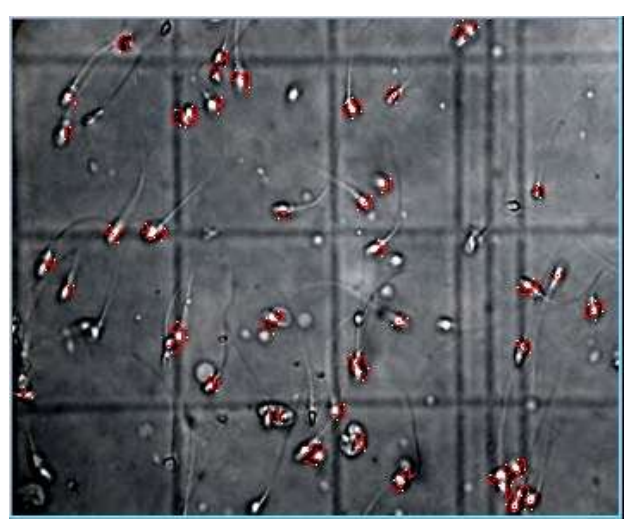

Gambar 8. Hasil Ellipse Detection

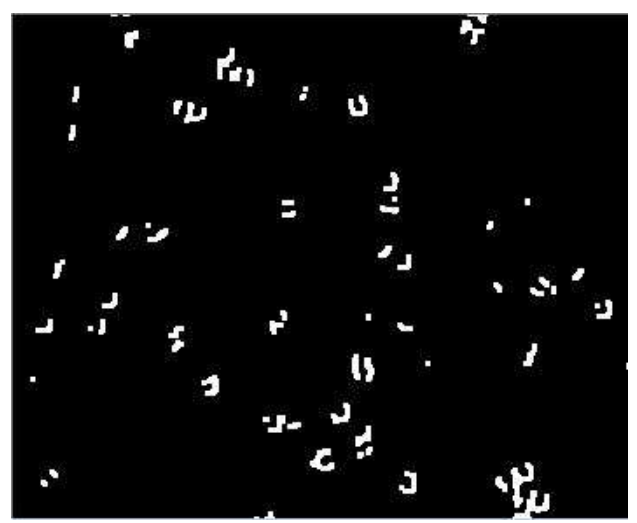

Gambar 9. Hasil Opening

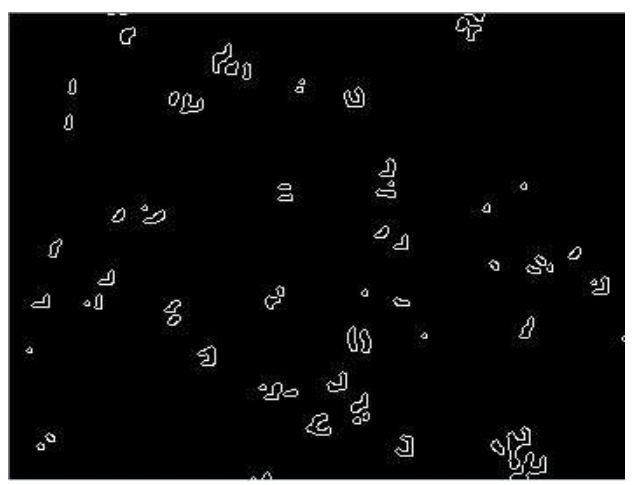

Gambar 10. Hasil Canny Edge Detection 


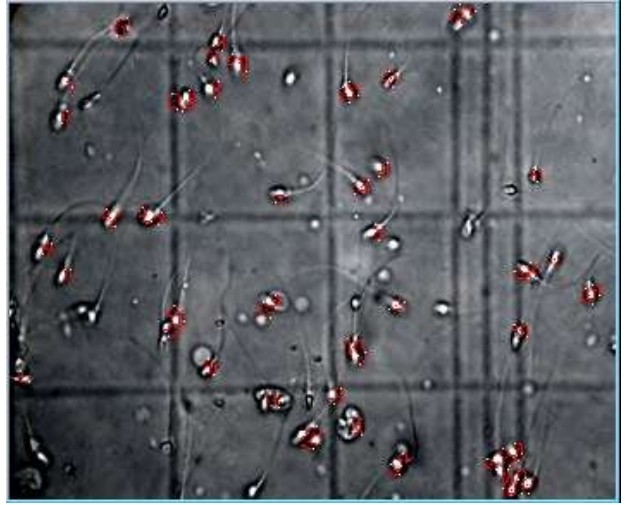

Gambar 11. Hasil Ellipse Detection

Seperti pada gambar 8, masih terdapat beberapa sperma yang tidak terdeteksi. Hal ini dianggap wajar dikarenakan pendeteksian sperma dengan menggunakan Adaptive Local Threshold dan Ellipse Detection memiliki tingkat akurasi deteksi 90.97\% [3].

\section{Adaptive Local Threshold}

Langkah awal dalam memisahkan background dengan objek yang akan dideteksi adalah dengan cara melakukan konversi dari citra grayscale menjadi citra biner. Untuk mendapatkan citra biner, perlu ditentukan terlebih dahulu batas (threshold) dari nilai suatu piksel agar kemudian menjadi hitam maupun putih.

Untuk binarisasi, Hidayatullah menggunakan data statistik lokal seperti Nilai rata-rata (mean) dan standar deviasi. Nilai rata-rata dari area lokal menunjukkan nilai rata-rata tingkat grayscale di area tersebut sedangkan standar deviasi menunjukkan nilai kontras. Metode ini dapat ditulis dengan persamaan (1).

$$
\mathrm{p}^{\prime}(\mathrm{x}, \mathrm{y})=\left\{\begin{array}{cc}
255 & \text { if } p(x, y)<\text { mean AND std } \geq \text { gStd } \\
0 & \text { otherwise }
\end{array}\right.
$$

Dimana $\mathrm{p}^{\prime}(\mathrm{x}, \mathrm{y})$ adalah nilai pixel, mean adalah nilai rata-rata dari area lokal, std adalah standar deviasi dari nilai area lokal, dan gStd adalah nilai standar global deviasi citra.

\section{Ellipse Detection}

Metode pendeteksi elips dipilih karena bentuk kepala sperma mirip dengan bentuk elips. Metode Ellipse Detection yang dibuat oleh Hidayatullah [3] merupakan modifikasi dari metode Ellipse Detection yang dibuat oleh Xie [6] agar dapat memberikan toleransi terhadap bentuk kepala sperma yang tidak sepenuhnya berbentuk elips. Batas minimal toleransi suatu objek dapat dikategorikan sebagai elips adalah apabila piksel yang terdeteksi sebagai tepi sudah memenuhi $3 / 4$ bentuk elips.
Metode Ellipse Detection oleh Xie dapat digambarkan dengan ilustrasi seperti Gambar 16. Metode ini dapat dituliskan dengan persamaan (4) (8).

Metode Ellipse Detection oleh Hidayatullah dapat ditulis dengan persamaan (2) - (13).

$$
\begin{aligned}
& x 0=\frac{x_{1}+x_{2}}{2} \\
& y 0=\frac{y_{1}+y_{2}}{2}
\end{aligned}
$$

$a=\frac{\left[\left(x_{2}-x_{1}\right)^{2}+\left(y_{2}-y_{1}\right)^{2}\right]^{\frac{1}{2}}}{2}$

$\propto=\operatorname{atan}\left[\frac{y_{2}-y_{1}}{x_{2}-x_{1}}\right]$

$$
b=\frac{a^{2} d^{2} \sin ^{2} \tau}{a^{2}-d^{2} \cos ^{2} \tau}
$$

$$
\text { dimana } \cos \tau \text { adalah }
$$

$\cos \tau=\frac{a^{2}+d^{2}-f^{2}}{2 a d}$

$k_{1}=x_{2} k_{2}=\min (x+\operatorname{dist}+1)$

$l_{1}=\max \left(y-\operatorname{dist}\left(1-0^{x^{\prime}-1}\right), 0\right)$

$l_{\mathbf{z}}=\min ($ width,$\quad y+\operatorname{dist}+1)$

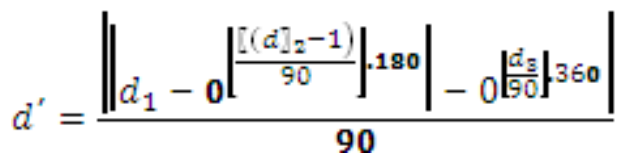

$\max$ Area $=\max \left(\max\right.$ Area $\left.-1, \frac{\text { totalVotes }-1}{4}+1\right)$

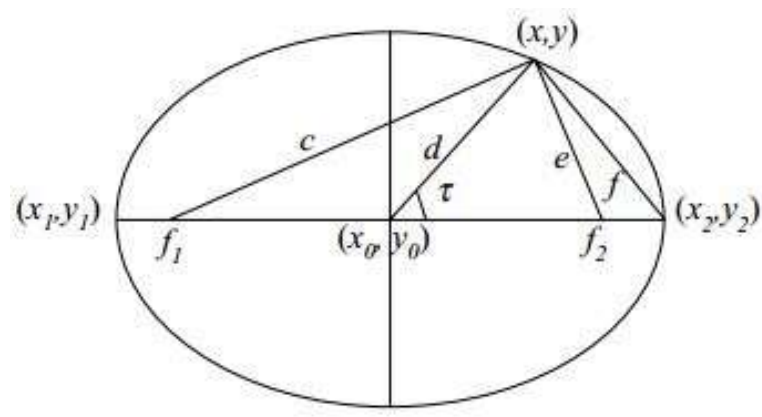

Gambar 12. Metode Ellipse Detection Xie [6]

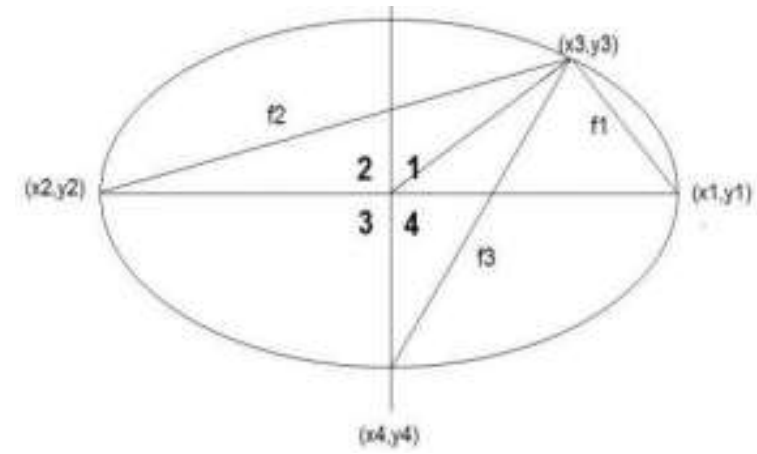

Gambar 13. Metode Ellipse Detection Hidayatullah [3] 
difference $=4 \cdot \max$ Area - totalVotes

tolerance $=\frac{\text { max Area }+1}{2}$

minVote $=\max \left(7, \frac{3}{4}\right.$, totalVotes $)$

dimana:

$\mathrm{x}_{0}$ dan $\mathrm{y}_{0}=$ titik pusat elips,

a $\quad=$ setengah panjang mayor axis,

$\mathrm{b}=$ = setengah panjang minor axis,

$\alpha \quad=$ sudut orientasi elips,

$\mathrm{d}=$ jarak antara titik pusat $\left(\mathrm{x}_{0}, \mathrm{y}_{0}\right)$ dan $(\mathrm{x}, \mathrm{y})$ pada gambar 10 ,

maxArea $=$ total piksel tertinggi pada sebuah quarter elips,

vote $\quad=$ nilai maksimal dari beberapa minor axis yang terdeteksi,

totalVotes $=$ jumlah nilai vote atau jumlah piksel yang terdeteksi,

difference $=$ selisih nilai total Votes yang diharapkan dengan nilai total Votes sebenarnya,

tolerance $=$ nilai difference maksimum agar suatu objek dapat dikatakan sebagai elips, dan

minVote = nilai minimal dari vote agar suatu objek dapat dikatakan sebagai elips. Dalam kasus ini ditentukan ukuran sperma minimal 7 piksel atau $3 / 4$ dari seluruh piksel yang terdeteksi (totalVotes).

\section{Matching ID Sperma}

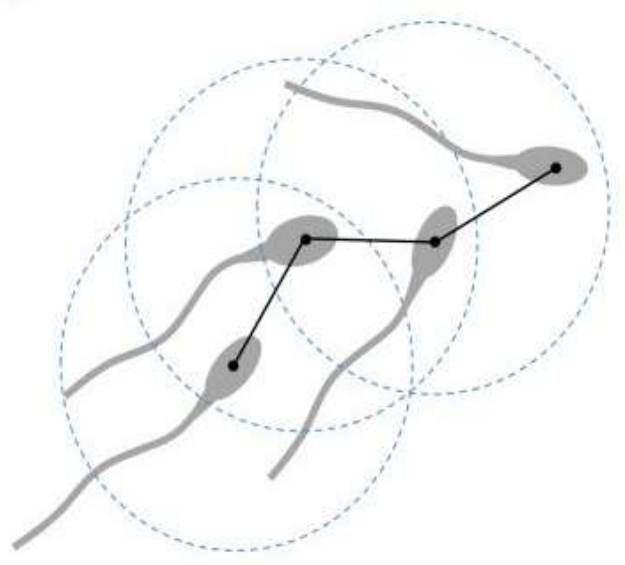

Gambar 11. Batas pencarian pergerakan sperma

Metode pencocokan ID Sperma pada penelitian ini adalah dengan menggunakan nilai batas pencarian pergerakan sperma seperti ilustrasi pada gambar 11 . Apabila sperma berada dalam batas pencarian suatu sperma pada frame sebelumnya, maka sperma tersebut dianggap sebagai sperma dengan ID yang sama.

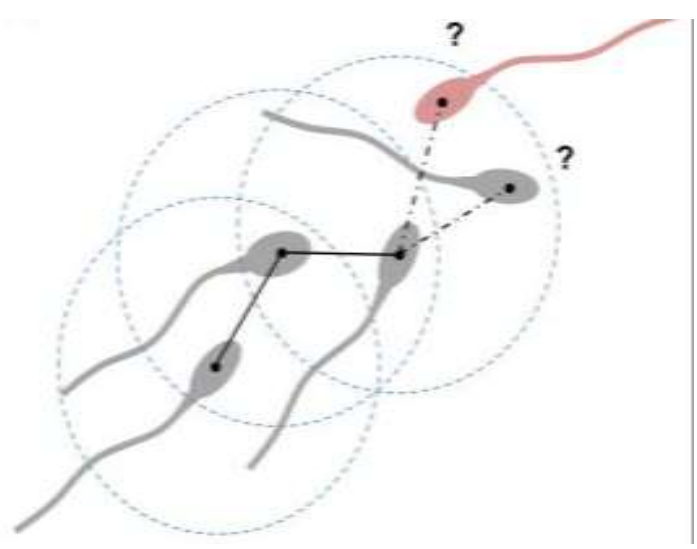

Gambar 12. Selisih jarak terkecil

Untuk menanggulangi apabila terjadi kondisi dimana terdapat lebih dari 1 sperma yang berada dalam batas pencarian seperti ilustrasi pada gambar 12, akan digunakan selisih jarak terkecil. Sehingga sperma yang berada dalam batas pencarian suatu sperma dengan selisih jarak terkecil dibandingkan sperma pada frame sebelumnya yang menjadi titik pusat dianggap sebagai sperma dengan ID yang sama.

\section{Linearitas Sperma}

Linearitas sperma adalah tingkat linearitas lintasan gerak sperma [4]. Berdasarkan standar prosedur manual WHO untuk pengujian semen manusia, nilai linearitas sperma didapat dengan cara membagi kecepatan kepala sperma pada garis lurus dari titik awal hingga akhir deteksi (Velocity Straight Line) dengan kecepatan kepala sperma pada lintasan berliku yang terlihat secara 2 dimensi yang nampak pada mikroskop (Velocity Curvilinear Line) [4].

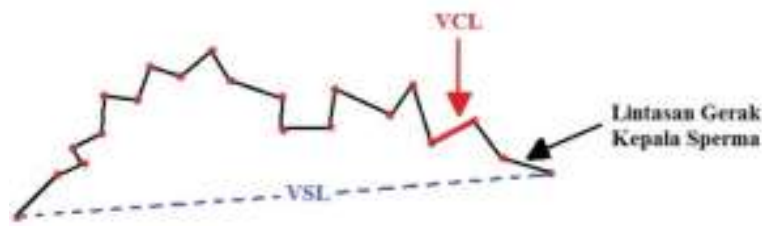

Gambar 13. Linearitas gerak sperma

Maka untuk mendapatkan linearitas sperma (LIN) dapat ditulis dengan persamaan (14).

$L N N_{i}=\frac{V S L_{i}}{V C L_{i}}$

sedangkan Velocity Straight Line (VSL) dan Velocity Curved Line (VCL) didapat dengan persamaan (23) dan (24).

$V S L_{i}=\frac{\sqrt{\left(x_{M}-x_{1}\right)^{2}+\left(y_{M}-y_{1}\right)^{2}}}{(M-1) \Delta t}$
$V C L_{i}=\frac{\sum_{j=1}^{M} \sqrt{\left(x_{j+1}-x_{j}\right)^{2}+\left(y_{j+1}-y_{j}\right)^{2}}}{(M-1) \Delta t}$ 
dimana i adalah index sperma, $M$ adalah jumlah frame atau frame akhir dari video, delta $t$ dalah selisih waktu antar frame, $\left(\mathrm{x}_{1}, \mathrm{y}_{1}\right)$ merupakan lokasi titik awal kepala sperma terdeteksi dan $\left(\mathrm{x}_{M}, \mathrm{y}_{M}\right)$ merupakan lokasi titik akhir kepala sperma.

Berdasarkan nilai linearitas sperma yang didapatkan, sperma kemudian akan diklasifikasikan menjadi 3 kategori berdasarkan [5], yakni:

Tabel 1 Kriteria linearitas sperma

\begin{tabular}{cc}
\hline Golongan & Kriteria (Nilai Linearitas) \\
\hline A & $>60 \%$ \\
B & $20 \%-60 \%$ \\
C & $<20 \%$
\end{tabular}

Konversi piksel ke micrometer

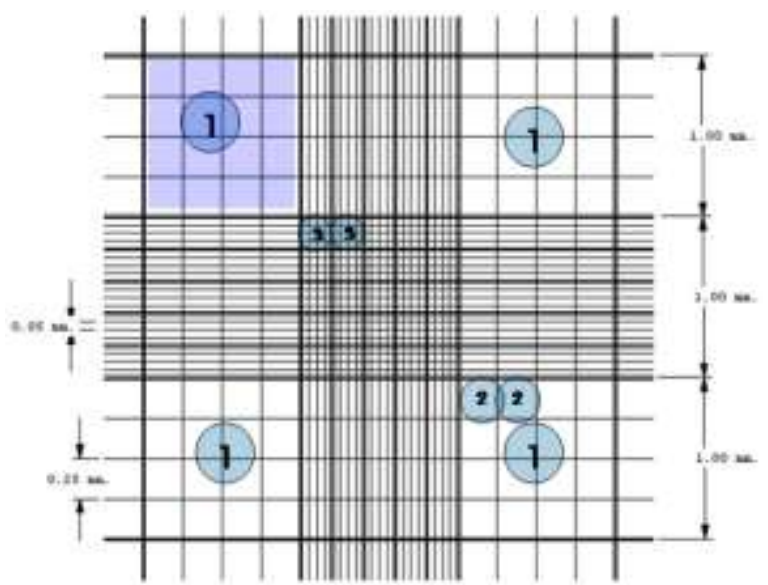

Gambar 14. Gambar kamar hitung Neubauer Improved

Pada penelitian ini, kamar hitung berfungsi sebagai alat bantu untuk mengukur jarak yang dilalui sperma. Kamar hitung yang digunakan adalah kamar hitung Neubauer Improved. Kotak yang digunakan adalah kotak kecil yang terdapat pada kotak nomor 3 pada gambar 14 atau dengan ukuran sisi masingmasing $0.05 \mathrm{~mm} \times 0.05 \mathrm{~mm}$.

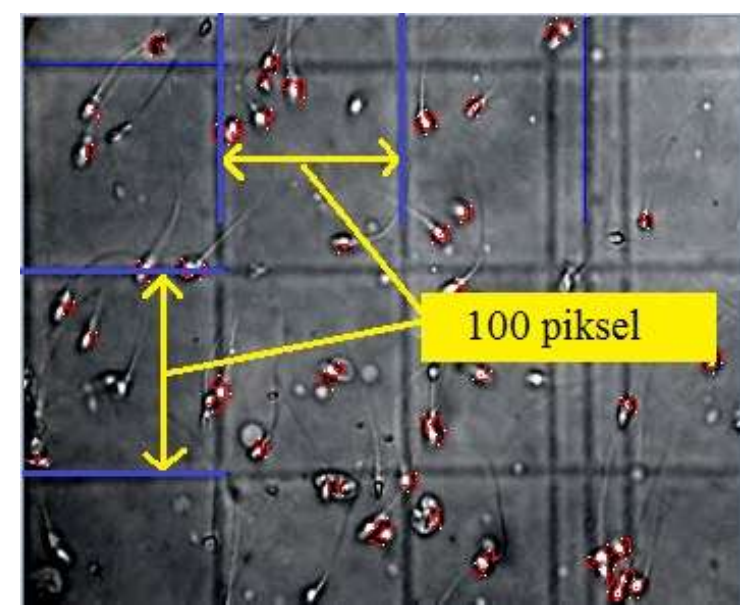

Gambar 15. Tampilan kamar hitung oleh mikroskop

\section{HASIL DAN PEMBAHASAN}

\section{Lingkungan implementasi}

Implementasi dilakukan menggunakan laptop dengan spesifikasi hardware berupa prosesor Inter ${ }^{\circledR}$ Core ${ }^{\mathrm{TM}}$ i3-350M CPU @ 2.27 GHz, RAM 3 GB, dan HDD 500 GB. Software yang digunakan adalah OS Windows 732-bit, bahasa pemrograman $\mathrm{C}++$ dengan IDE Code::Blocks 13.12 dan API OpenCV.

\section{Hasil pengujian}

Tabel 2. Hasil Eksperimen Menggunakan Sampel Video 30 fps selama 1 detik

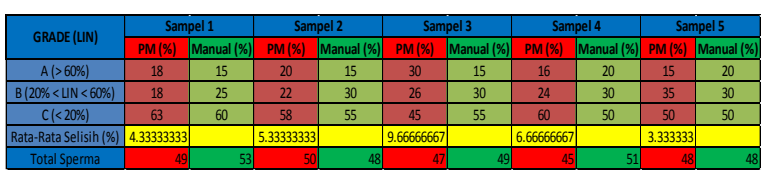

Tabel 3. Hasil Eksperimen Menggunakan Sampel Video 30 fps selama 3,5 detik

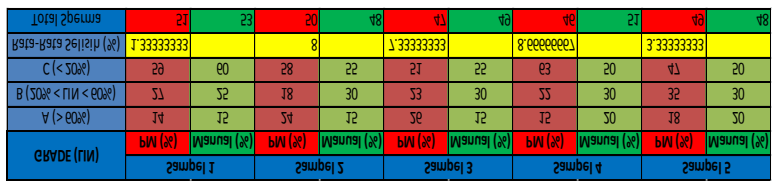

Tabel 4. Hasil Eksperimen Menggunakan Sampel Video 60 fps selama 1 detik

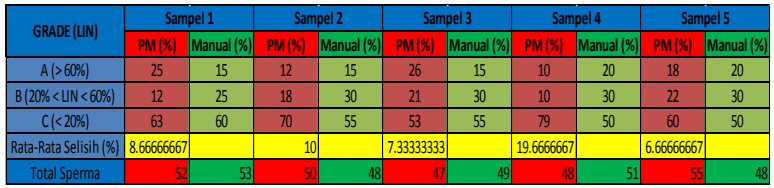

Tabel 5. Hasil Eksperimen Menggunakan Sampel Video 60 fps selama 3,5 detik

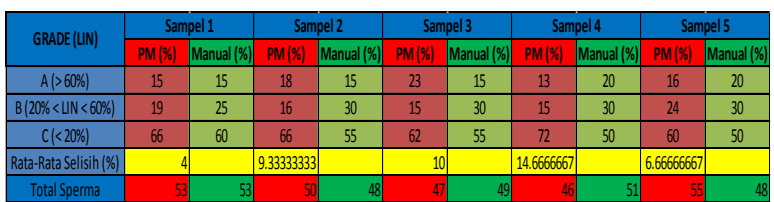

Tabel 6. Spesifikasi

\begin{tabular}{c|c}
\hline Video Uji & Total Selisih Akurasi (\%) \\
\hline 30 fps 1 Detik & 5.866666667 \\
\hline $60 \mathrm{fps}$ 1 Detik & 5.733333333 \\
\hline $30 \mathrm{fps}$ 3.5 Detik & 10.46666667 \\
\hline $60 \mathrm{fps}$ 3.5 Detik & 8.933333333 \\
\hline
\end{tabular}

Keterangan:

$\mathrm{PM}=$ Perhitungan menggunakan proposed method (metode yang dirancang); Manual = Perhitungan secara manual dengan menggunakan pengamatan visual Laboran Klinis; Rata-Rata Selisih = Rata-rata dari selisih hasil analisis motilitas sperma meng- 
gunakan PM dan Manual (dalam \%); Total Selisih Akurasi $=$ Rata-rata dari selisih hasil analisis motilitas sperma dari 5 video menggunakan PM dan Manual (dalam \%).

Berdasarkan hasil eksperimen didapat bahwa dengan menggunakan sampel video dengan frame rate 60 fps selama 1 detik memiliki selisih akurasi yang lebih kecil dibandingkan menggunakan sampel video dengan frame rate 30 fps selama 1 detik. Hasil ini berbanding lurus dengan teori dimana frame rate yang lebih besar akan menghasilkan data yang lebih akurat karena selisih pergerakan sperma antar frame menjadi semakin kecil. Namun eksperimen dengan menggunakan sampel video dengan frame rate $30 \mathrm{fps}$ dan 60 fps selama 3,5 detik menghasilkan selisih akurasi yang lebih besar dibandingkan selama 1 detik. Perbedaan hasil analisis atau selisih dapat disebabkan karena aturan batas pergerakan maksimal sperma yang diterapkan pada metode ini. Besaran dari batas pergerakan sperma yang tidak tepat dapat menimbulkan suatu permasalahan baru akibat kesalahan saat pencocokan ID sperma. Apabila nilai batas pergerakkan terlalu kecil, maka ada kemungkinan sperma yang bergerak cepat mungkin tidak terdeteksi sebagai sperma dengan ID yang sama pada frame selanjutnya. Jika nilai batas pergerakan terlalu besar, maka dapat menimbulkan ambiguitas pemberian ID terhadap lebih dari 1 sperma terdeteksi yang termasuk didalam batasan tersebut.

Salah satu solusi untuk menaggulangi data posisi sperma yang diluar batas toleransi adalah dengan memperkecil selisih pergerakan sperma antar frame yakni dengan cara meningkatkan frame rate video. Seperti pada eksperimen ini dimana video dengan frame rate $60 \mathrm{fps}$ selama memiliki selisih akurasi yang lebih kecil dibandingkan menggunakan sampel video dengan frame rate $30 \mathrm{fps}$.

Namun masalah utama yang perlu diselesaikan adalah membuat agar data posisi sperma yang pernah terdeteksi tidak hilang di salah satu frame, antara lain dengan menambahkan metode object tracking yang lebih robust.

\section{KESIMPULAN DAN SARAN}

Berdasarkan hasil eksperimen terhadap 10 video sampel sperma, pengukuran tingkat motilitas sperma berdasarkan linearitas sperma menggunakan metode Adaptive Local Threshold dan Ellipse Detection dapat memberikan hasil dengan selisih rata-rata total terkecil sebesar 5,7\% dan terbesar sebesar 10,46\% bila dibandingkan dengan pengukuran secara visual oleh androlog. Selain itu frame rate video menentukan hasil analisis. Video dengan frame rate yang semakin tinggi dapat memberikan hasil analisis dengan selisih yang semakin kecil. Faktor yang menyebabkan kesalahan dalam pengukuran adalah adanya kemungkinan suatu sperma tidak selalu terdeteksi pada seluruh frame, sehingga memungkinkan terdapat kesalahan data posisi sperma antar frame yang berbeda.

Untuk penelitian selanjutnya disarankan agar menggabungkan antara metode sperm detection dan object tracking agar data posisi sperma menjadi lebih robust. Selain itu menambahkan parameter motilitas sperma diluar VSL, VCL, dan LIN untuk meningkatkan kehandalan hasil pengukuran.

\section{DAFTAR PUSTAKA}

[1] Witkowski, L., Examinations of the Density of Semen and Analysis of Sperm Cell Movement. Journal of Medical Informatics \& Technologicies, 2002, Vol. 3.

[2] Urbano, L.F., Robust Automatic Multi-Sperm Tracking in Time-Lapse Images. Drexel: Drexel University, 2014.

[3] Hidayatullah, P. \& Zuhdi, M., Automatic Sperms Counting using Adaptive Local Threshold and Ellipse Detection. ICITSI, 2015.

[4] World Health Organization. WHO Laboratory Manual for The Examination of Human Semen and Sperm-Cervical Mucus Interaction. $5^{\text {th }}$ Edition. Penerbit Cambridge University Press, 2010.

[5] Kraemer, M., Fillion, C., Martin-Pont, B. \& Auger, J. Factors influencing human sperm kinematic measurements by the Celltrak computer-assisted sperm analysis system. Human Reproduction, 1998, vol. 13, no. 3, pp. 611-619.

[6] Xie, Y. \& Ji, Q. A New Efficient Ellipse Detection Method. Proceedings 16th International Conference on IEEE, 2002, Vol 2, p. 957-60.

[7] Suparsa, I.P.A. 2012. Kamar Hitung. Error! Hyperlink reference not valid. [21 Juni 2015]

[8] Bradski, G. \& Kaehler, A.Learning Open CV. $1^{\text {st }}$ edition. Penerbit O'Reilly, 2008. 